\title{
СОЦІАЛЬНО-ПСИХОЛОГІЧНА РЕАБІЛІТАЦІЯ УЧАСНИКІВ БОЙОВИХ ДІЙ
}

УДК: 159.09 .07

\section{Макаренко Стефанія Стефанівна}

Кандидат психологічних наук, доцент кафедри теоретичної та практичної психології, дочент Інституту права і психології Начіонального університету «Львівська політехніка», м. Львів (Україна)

\begin{abstract}
Анотація. В статті представлено напрям роботи психологічної служби психологічна реабілітація як один з видів допомоги, яку надає кваліфікований психолог людині або групі людей з метою оптимізації психофізіологічних станів, пізнавальних прочесів, поведінки, спілкування, реалізащії індивідуальної та, особливо, групової діяльності. Увага суб'єктів психологічної роботи спрямована на відновлення психічних функцій, особистісних властивостей $i$ системи відносин особистості військовослужбовця, щзо дозволяє йому успішно вирішувати бойові завдання і функціонувати в мирному соиіумі. Тобто об'єктом реабілітації є особи, які отримали бойову психічну травму, щчо проявляється гостро або відтермінована в часі.

Психологічна реабілітація воїнів АТО, щуо отримали психічну травму під час проведення бойових дій, спрямована на визначення ї̈ психологічної структури з метою оптимізації розвитку і функціонування індивіда в конкретних умовах життєдіяльності.
\end{abstract}

Ключові слова: психолог, військовий психолог, психологічна реабілітація, військовослужбовецьь, психокорекиія, психологічна підтримка, психологічна допомога, психічний стан.

Постановка проблеми. Ситуація, яку переживає Україна впродовж декількох років, $€$ такою, що виходить за межі звичайного людського досвіду. Військові дії спричиняють значне порушення життєдіяльності людей, шкоду їх здоров’ю, і зокрема, психічному. Вочевидь гостро постає потреба у психологічній допомозі та супроводі цілих соціальних груп, а також у психологічній допомозі окремим людям - дітям, дорослим, постраждалим родинам, i, особливо, дорослим військовозобов'язаним чоловікам, які можуть бути або були задіяні у військових діях. Одночасно актуальною стає необхідність методологічного та методичного забезпечення цієї роботи: розроблення програм та методичного інструментарію для окремих іiї напрямів, у тому числі для 
підвищення стресостійкості військовослужбовців.

Зміст психологічної допомоги полягає у забезпеченні емоційної, смислової й екзистенційної підтримки людини або суспільства в ситуаціях ускладнення, які виникають під час їхнього особистісного й соціального буття. Також, психологічну допомогу розглядають, як вид допомоги, яку надає кваліфікований психолог людині або групі людей з метою оптимізації психофізіологічних станів, пізнавальних процесів, поведінки, спілкування, реалізації індивідуальної та, особливо, групової діяльності.

У контексті нашого дослідження слід зазначити, що в психологічній літературі найчастіше зустрічається поняття «психологічна реабілітація» як комплекс профілактичних, лікувальних та евакуаційних заходів, що забезпечують збереження психічного здоров'я військовослужбовців як основи їх боєздатноcri [6].

За визначенням О. Блінова, П. Криворучко, В. Марченко під поняттям «психологічна реабілітація», як стрижнем діяльності психолога 3 персоналом, відображається певна реальність, деяка психосоціальна практика, поле діяльності якої є сукупність питань, ускладнень і проблем, що причетні до психічного життя людини [7 ].

Важливо зауважити, що досвід участі воїнів в локальних війнах та збройних конфліктах в кінці XX на початку XXI сторіччя переконливо свідчить про високий рівень психічної травматизації військових, а саме, теперішні події на Сході країни є яскравим прикладом психічної травматизації військовослужбовців, які перебувають на полі бою. Тому важливо зазначити, що для підвищення рівня боєздатності, а також збереження їх психічного здоров'я $є$ необхідною організація та здійснення психологічної допомоги.

\section{Аналіз останніх досліджень і публі-}

кацій. Дослідження проблеми психологічної реабілітації військовослужбовців, які брали участь у військових діях, представлені в працях як зарубіжних науковців (I. Баєва, I. Блінов, В. Вилюнас, К. Ізард, Н. Коупленд, М. Фрідман, Р. Кадиров, О. Караяні та ін.), так і українських дослідників (А. Бондаренко, М. Корольчук, С. Максименко, Г. Тімченко та ін.).

Серед вітчизняних та зарубіжних дослідників питання, пов'язані з різними аспектами психологічної допомоги військовослужбовцям, також розглядали: Г. Акімов, О. Лобастов, Р. Грінкер, Д. Шпігель (наслідки бойових психічних травм під час світових війн), В. Гічун, В. Ковтун, О. Коржиков, Ю. Лях (медико-соціальні аспекти реабілітації військовослужбовців); В. Березовець, С. Захарик, В. Знаков, І. Ліпатов, $\quad$ Т. Пароянц, В. Попов, П. Сідоров, В. Стасюк (наслідки бойових психічних травм під час воєнних конфліктів) та ін. 
Мета статті. В результаті теоретикоемпіричного дослідження визначити алгоритм роботи психолога щодо надання психологічної реабілітації воїнам АТО, які отримали психічну травму під час проведення бойових дій.

Виклад основного матеріалу і результатів дослідження. Вивчення вітчизняного та зарубіжного досвіду надання психологічної реабілітації військовослужбовцям, які брали участь у бойових діях, дає змогу дійти висновку, що така робота має розпочинатися відповідними фахівцями (у першу чергу, військовими психологами та медиками) ще на етапі виходу військовослужбовців 3 району ведення бойових дій. Мова йде про необхідність перебудови їхньої системи відносин та пристосування до важливих сторін життєдіяльності. У разі отримання важких бойових психічних травм психологічна допомога, в першу чергу, має організовуватися медичними фахівцями. Вона може проводитися в традиційному вигляді й бути частиною медично-психологічної реабілітації. Крім цього, її слід проводити з військовослужбовцями, що проходять лікування у зв'язку з пораненнями, контузіями, травмами, опіками, опромінюванням, психічними розладами.

Отже, психологічна реабілітація $є$ галуззю й способом діяльності, що призначена для сприяння людині й суспільству в розв'язанні широкого колу проблем, породжених душевним життям людини в соціумі. Зміст психологічної допомоги полягає у забезпеченні емоційної, смислової й екзистенційної підтримки людини або суспільства в ситуаціях ускладнення, які виникають під час їхнього особистісного й соціального буття.

На основі аналізу науково-психологічної літератури можна визначити, що психологічна реабілітація учасників бойових дій - це комплекс профілактичних, лікувальних та евакуаційних заходів, які забезпечують збереження психічного здоров'я військовослужбовців як основи їх боєздатності. До основних форм здійснення психологічної роботи належать: психодіагностика, психопрофілактика і психогігієна, психологічне консультування та освіта, психотерапія і психореабілітація.

I. Приходько, І. Ліпатов та Л. Шестопалова у загальному плані надання психологічної реабілітації військовослужбовцям виокремлюють два напрями роботи [8 ]:

1. Виховна робота командирів всіх рівнів та їх організаторська діяльність зі створення у військових підрозділах умов, які запобігають негативним виявам нервовопсихічної нестійкості і кризових станів військовослужбовців.

2. Проведення психологом військової частини спеціального психологічного впливу. Використовуються різноманітні прийоми i процедури, об'єднані в рамках таких видів психологічної допомоги, як психологічне консультування, психотерапія і психореабілітація. 
На думку Б. Бархаєва, психологічна допомога як одна з форм діяльності фахівців, входить до складу психологічної роботи 3 військовослужбовцями. О. Тімченко разом 3 іншими авторами вважає, що у загальному вигляді психологічна допомога трактується як професійна допомога психолога з вирішення психологічних проблем клієнта.

Отже, виходячи 3 аналізу науковотеоретичних джерел за визначеною проблематикою нами з'ясовано, що проблема надання психологічної допомоги учасникам бойових дій потребує подальшого розвитку через вдосконалення основних форм здійснення психологічної роботи в частині психодіагностики, психопрофілактики і психогігієни, психологічному консультуванні та освіті, психотерапії і психореабілітації.

Зазначимо, що існує досить чітка система надання психологічної допомоги військовослужбовцям, що мають певні проблеми 3 психічним здоров'ям чи отримали суттєві бойові психічні травми. На сьогодні розроблено три концептуальних підходи щодо надання психологічної допомоги у бойових ситуаціях - це американська, ізраїльська та російська системи [9 ].

Американська система надання психологічної допомоги організована таким чином: командир підрозділу та молодший медичний спеціаліст виявляють осіб з бойовими психічними травмами і надають їм негайну психологічну допомогу, після чого відправляють постраждалого в батальйонний медичний пункт. Тут їм надається долікарська психологічна допомога (сон, тепло, якісне годування, відпочинок і мінімальна кількість фармакологічних препаратів) протягом кількох годин. Протягом двох тижнів, окрім вищеперелічених заходів, 3 постраждалими проводяться ненапружені заняття 3 бойової підготовки, організуються зустрічі 3 іншими військовослужбовцями, заходи психологічної та психіатричної допомоги. Для надання такої допомоги в медичній роті $є$ психолог, психіатр і соціолог. При відсутності позитивних результатів лікування продовжується у психіатричному закладі чи стаціонарному шпиталі. За оцінками спеціалістів, ефективність такої допомоги складає 45-75\% .

Ізраїльська система психологічної допомоги має комплексний характер і передбачає виявлення командирами безпосередньо у підрозділі осіб з ознаками бойових психічних травм. Ці військовослужбовці відправляються в батальйонний медичний пункт, де 3 ними здійснюється психотерапевтична робота протягом кількох годин. 3 цією метою можуть використовуватися психотерапія, при необхідності медикаментозні засоби, в основному, снотворні, організується зв'язок з командирами, іншими військовослужбовцями. Коли така система заходів не дає позитивного результату, постраждали відправляються в дивізійну медичну роту терміном до двох тижнів. За 
оцінками спеціалістів, ефективність такої допомоги складає 25-55\%.

Російська система психологічної допомоги веде свої традиції з російсько-японської війни 1905 року. Вона отримала певне вдосконалення в роки першої та другої світових воїн. Ця система характеризується тим, що психологічна допомога надається переважно воїнам 3 психотичними та психічними розладами, що розвиваються на тлі фізичних поранень i травм. У ході бойових дій у «гарячих» районах апробовано роботу спеціальної групи психологічної (психофізіологічної) допомоги, яка складається з психіатрів, психофізіологів, психофармакологів. Вони довели власну життездатність і корисність. За оцінками спеціалістів, ефективність такої допомоги складає 15$45 \%$.

Досвід участі іноземних військ у військових подіях останнього часу переконливо підтверджує той факт, що система комплексної психологічної допомоги учасникам бойових дій є необхідною. Без належної системи психологічної допомоги, вкрай складно досягти високої бойової активності воїнів і ефективного розв'язання ними бойових завдань у локальних військових конфліктах.

Надання комплексної психологічної допомоги військовослужбовцям, які отримали психічну травму, матиме на меті забезпечити психологічним супроводом військових, сприяти мобілізації й активізації бойової готовності та боєздатності, знизити психологічне напру- ження та втому, швидко повернути в підрозділи військовослужбовців, які за характером психічних травм не потребують госпіталізації, відновлення психологічної стійкості дезорганізованих підрозділів. Також, система комплексної психологічної допомоги, повинна враховувати досвід локальних війн, згідно досвіду яких були сформовані такі основні принципи психологічної допомоги: [10].

Наближеність - психологічна допомога повинна бути максимально наближеною до підрозділу, проводитися в ньому.

Швидкість - реабілітаційні заходи потрібно застосовувати у найкоротший термін, відразу після виявлення ознак психічних розладів.

Надійність - організація психологічної допомоги повинна передбачати формування i підтримку у віськовослужбовців впевненості в обов'язковому отриманні необхідної медичної допомоги.

Простота - діагностичні, лікувальні та реабілітаційні заходи повинні бути нескладними, загальнодоступними .

Отже, можна припустити, що система надання комплексної психологічної допомоги учасникам бойових дій включатиме в себе діагностику, профілактику, консультування, психологічну корекцію та психотерапію, яка має здійснюватися кваліфікованим психологом, який повинен співпрацювати із командиром підрозділу та медичним працівником. 
Організація і проведення психодіагностичних заходів із військовослужбовцями є невід'ємною частиною забезпечення комплексної психологічної допомоги. Багато структур різного типу (державних і громадських організацій, благодійних фондів) здійснюють допомогу військовозобов'язаним і учасникам бойових дій, зокрема.

Для вдосконалення системи надання комплексної психологічної допомоги воїнам ATO, які отримали психічну травму під час проведення бойових дій та вироблення алгоритму роботи практичного психолога, нами було проведено емпіричне дослідження у «Центрі Надання Послуг Учасникам Бойових Дій» (м. Львів, вул. Пекарська 41), який є Державною організацією і був створений для надання послуг учасникам бойових дій, сім'ям загиблих, військовим частинам та іншим військовим формуванням, а також у зв'язку з необхідністю координації дій волонтерів і громадських організацій, які надають допомогу учасникам АТО та їх сім'ям.

Особливу увагу при цьому було звернено на результати психодіагностики, як компоненту комплексної психологічної допомоги військовим, що дало змогу побачити симптоматику проявів тих чи інших психічних розладів.

Вибірку склали 50 респондентів, які перебували на реабілітації в «Центрі Надання Послуг Учасникам Бойових Дій» після повер- нення із зони АТО та зазнали емоційних стресів.

Підставою для проведення емпіричного дослідження стали скарги (що були отримані в ході клінічного інтерв'ю) учасників бойових дій на підвищену агресивність, прояви тривожності, проблеми в спілкуванні з людьми.

За допомогою методики «Самооцінка психічних станів» (Г. Айзенка) було визначено психічні стани досліджуваних за чотирма шкалами: тривожність, фрустрація, агресивність і ригідність, які характеризувалися високим, середнім і низьким рівнем прояву цих станів. Отримані результати представлені на Рис. 1.

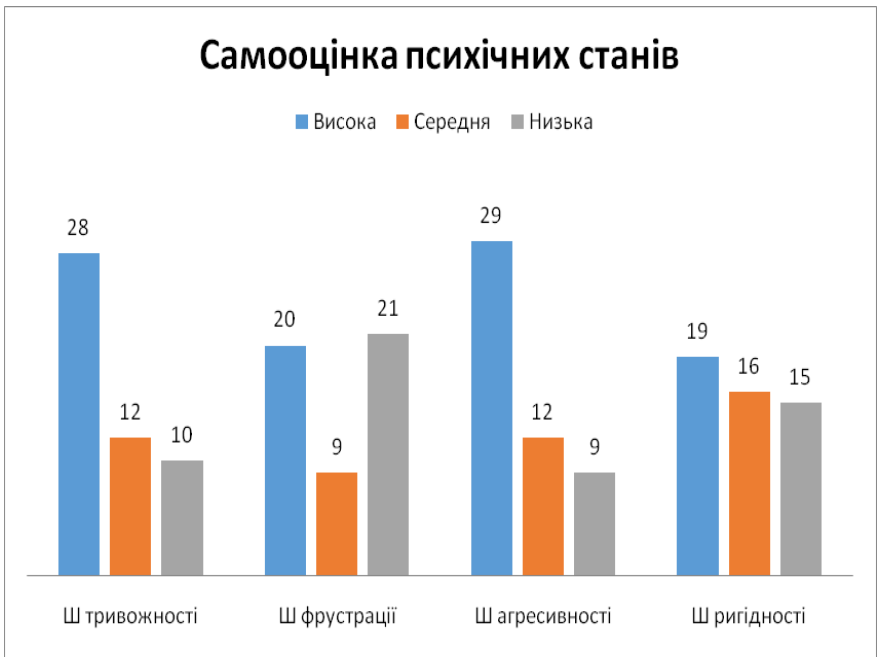

\section{Рис. 1. Самооцінка психічних станів дослі- джуваних}

Проведене психологічне дослідження самооцінки психічних станів респондентів, учасників бойових дій (які знаходилися в реабілітаційному центрі) показало, що у 28 досліджуваних спостерігався високий рівень триво- 
жності; у 12 респондентів - середній рівень тривожності, у 10 респондентів діагностовано низький рівень тривожності.

Результати діагностики самооцінки психічних станів досліджуваних за шкалою агресивності виявили у 29 респондентів високий рівень агресивності; середній рівень агресивності - у 12 респондентів; лише у 9 учасників бойових дій діагностовано низький рівень агресивності.

Діагностика самооцінки психічних станів за шкалою фрустрації показала, що у 20 респондентів (учасників бойових дій) спостерігався високий рівень прояву фрустрації, у 9 учасників - середній рівень прояву фрустрації та у 21 учасника бойових дій діагностовано низький рівень прояву фрустрації.

Діагностика самооцінки психічних станів за шкалою ригідності виявила у 19 учасників бойових дій високий рівень ригідності; у 16 учасників спостерігався середній рівень ригідності, а у 15 учасників бойових дій виявили низький рівень емоційних проявів ригідності.

Узагальнення результатів дослідження самооцінки психічних станів учасників бойових дій показало підвищений рівень агресивності, тривожності, фрустрації; проблеми в спілкуванні з людьми та інші емоційні негаразди, що проявлялися у всіх досліджуваних після повернення із зони бойових дій. Під час спілкування з воїнами АТО було виявлено погіршення їх психологічного та фізичного ста- ну після отримання психічної травми під час проведення бойових дій.

\section{Висновки та перспективи подаль-}

ших досліджень. На основі теоретико - емпіричного дослідження визначено особливості психологічної допомоги учасникам бойових дій, яка $\epsilon$ найефективнішим засобом впливу на психічне здоров'я воїнів АТО під час їх психологічної реабілітації.

Виявлено підвищений рівень агресивності, тривожності, ригідності та фрустрації у досліджуваних військовослужбовців (учасників бойових дій).

Перспективами подальших досліджень із заявленої проблеми буде вдосконалення заходів, які передбачають психодіагностику, індивідуальне консультування, психологічні дебрифінги, програми взаємної підтримки, психокорекційну роботу тощо.

\section{Перелік використаних джерел:}

1. Буднищька О. А. Індивідуально - особистісні детермінанти емоційних переживань у психотравмуючій ситуації: Автореф. дис. канд. психол. наук: / Київськ. нац. ун-т. - К., 2002 р. -77 c.

2. Блінов $O$. А. Види та напрямки психологічної допомоги психотравмованим військовослужбовцям / О. А. Блінов//Вісник Націнального університету оборони України. Зб-к наук. праць. - К. : НУОУ, 2014 р. Вип (4). -175 с.

3. Корольчук М. С., Корольчук В. М., Миронець С. М., Тімченко О.В., Осьодло В. І., Ржевський Г. М., Максименко К. С., Психологія праці в звичайних та екстремальних умовах / Навч. посіб. для студ. ВНЗ. - К. : Київ. нац. торг. ун-т, 2014p. -523 c. 
4. Коупленд Н. Психология и солдат/Пер, с англ. А. Т. Сапронова и Ю. М. Каторинича. - 2-е изд. - М.: Воениздат, 1991p. - 74 с.

5. Профілактика посттравматичних стресових розладів: психологічні аспекти : метод. посіб. / Упор. : Д. Д. Романовська, О. В. Ілащук. - Чернівці : Технодрук, 2014 p. -133 c.

6. Стасюк В. В. Система соціально-психологічного забезпечення функціонування військових підрозділів в умовах збройних конфліктів. - К.: НАОУ, 2005p. - 322 c.

7. Хміляр О. Ф. Психічна адаптація військовослужбовців до екстремальних ситуацій миротворчої місії // Науковий часопис НПУ імені М.П.Драгоманова. - Ceрія № 12. Психологія: Зб. наук. праць. - К.: НПУ імені М.П.Драгоманова, № 3 (27), 2005 р.- 215 с.

8. Ягупов В. В. Психологічна підготовка військовослужбовців до бойових дій як складова частина військоводидактичного процесу //

В. В. Ягупов. Військова дидактика. - К., 2000 р. - 254 с.

\section{References (Transliteration):}

1. Budnyts'ka O. A. Indyvidual'no - osobystisni determinanty emotsiynykh perezhyvan' u psykhotravmuyuchiy sytuatsiyi: Avtoref. dys. kand. psykhol. nauk: / Kyyivs'k. nats. un-t. - K., 2002 r. - 77 s.

2. Blinov $O$. A. Vydy ta napryamky psykholohichnoyi dopomohy psykhotravmovanym viys'kovosluzhbovtsyam / O. A. Blinov // Visnyk Natsional'noho universytetu oborony Ukrayiny. Zb-k nauk. prats'. - K. : NUOU, 2014 r. - Vyp (4). 175 s.

3. Korol'chuk M. S., Korol'chuk V. M., Myronets' S. M., Timchenko O.V., Os'odlo V. I., Rzhevs'kyy H. M., Maksymenko K. S. Psykholohiya pratsi v zvychaynykh ta ekstremal'nykh umovakh / Navchal'nyy posibnyk dlya studentiv VNZ. - K. : Kyyiv.nats.torh.un-t, 2014r. - 523 s.

4. Kouplend N. Psykholohyya y soldat/Per, s anhl. A. T. Sapronova y U. M. Katoryyycha. - 2-e yzd. - M.: Voenyzdat, 1991r. - 74 s.
5. Profilaktyka posttravmatychnykh stresovykh rozladiv: psykholohichni aspekty.Metodychnyy posibnyk / Upor. : D.D. Romanovs'ka, O.V. Ilashchuk. - Chernivtsi : Tekhnodruk, 2014 r. - 133 s.

6. Stasyuk $\quad V . \quad V$. Systema sotsial'no-psykholohichnoho zabezpechennya funktsionuvannya viys'kovykh pidrozdiliv v umovakh zbroynykh konfliktiv. - K.: NAOU, 2005r. $322 \mathrm{~s}$.

7. Khmilyar $O$. F. Psykhichna adaptatsiya viys'kovosluzhbovtsiv do ekstremal'nykh sytuatsiy myrotvorchoyi misiyi // Naukovyy chasopys NPU imeni M.P.Drahomanova. Seriya № 12. Psykholohiya: Zb. naukovykh prats'. - K.: NPU imeni M .P. Drahomanova, № 3 (27), 2005 r. -215 s.

8. Yahupov V. V. Psykholohichna pidhotovka viys'kovosluzhbovtsiv do boyovykh diy yak skladova chastyna viys'kovo-dydaktychnoho protsesu // Yahupov V.V. Viys'kova dydaktyka. - K., 2000 r. -254 s.

\section{Makarenko Stephanie}

PhD in Psychology, Associate Professor of the Department of Theoretical and Practical Psychology, Associate Professor Institute of Law and Psychology National University «Lviv Polytechnic», Lviv (Ukraine)

\section{SOCIO-PSYCHOLOGICAL REHABILITATION OF PARTICIPANTS IN COMBAT OPERATIONS}

\section{ABSTRACT}

The problem of studying the domestic and foreign experience of providing psychological assistance to military personnel participating in hostilities was highlighted. It is noted that such work should be carried out by the relevant specialists (first of all military psychologists and physicians) at the stage of withdrawal of military personnel from the area of combat operations. 
Psychological rehab is considered as a kind of assistance provided by a qualified psychologist to a person or group of people in order to optimize psychophysiological conditions, cognitive processes, behavior, communication, the implementation of individual and, especially, group activities.

Three conceptual approaches to providing psychological assistance in combat situations are analyzed - American, Israeli and Russian systems.

The psychological states of the subjects (soldiers who participated in combat operations in the ATO zone) were determined using the method "Self-assessment of mental states" (G. Eysenka) in four scales: anxiety, frustration, aggressiveness and rigidity, characterized by high, medium and low levels the manifestation of these states.

The generalization of the results of the study of the self-assessment of the mental states of the participants in the fighting showed an increased level of aggressiveness, anxiety, rigidity, frustration; problems in communicating with people and other emotional hardships manifested in all subjects after returning from the area of hostilities. During communication with soldiers ATO, deterioration of their psychological and physical condition after receiving a psychological trauma during the conduct of hostilities was revealed.

Prospects for further research on the stated problem will be the improvement of measures that include psychodiagnosis, individual counseling, psychological debriefing, mutual support programs, psycho-correctional work, etc.
Key words: psychologist, military psychologist, psychological rehabilitated serviceman, psychocorrection, psychological support, psychological help, mental condition.

\section{Макаренко Стефания Стефановна}

Кандидат психологических наук, дочент кафедры теоретической и практической психологии, дочент Института права и психологи Начионального университета «Львовская политехника», г. Львов (Украина)

\section{СОЦИАЛЬНО-ПСИХОЛОГИЧЕСКАЯ РЕАБИЛИТАЦИЯ УЧАСТНИКОВ БОЕВЫХ ДЕЙСТВИЙ}

Аннотация. В статье представлено направление работы психологической службы - психологическая реабилитация, как один из видов помощи, которую оказывает квалифицированный психолог человеку или группе людей с целью оптимизации психофизиологических состояний, познавательных процессов, поведения, общения, реализации индивидуальной и особенно групповой деятельности. Внимание, осуществляемое субъектами психологической работы, направлено на восстановление психических функций, личностных свойств и системы отношений личности военнослужащего, позволяющих ему успешно решать боевые задачи и работать в мирном социуме. То есть объектом реабилитации являются лица, получившие боевую психическую травму, которая проявляется остро или отсрочена во времени.

Психологическая реабилитация воинов АТО, получивших психическую травму во 
время проведения боевых действий, направлена на определение ее психологической структуры с целью оптимизации развития и функционирования индивида в конкретных условиях жизнедеятельности.

Ключевые слова: психолог, военный психолог, психологическая реабилитация, военнослужащий, психокоррекция, психологическая поддержка, психологическая помощь, психическое состояние. 